\title{
Evaluation of the Antibacterial and Antifungal Potential of Peltophorum africanum: Toxicological Effect on Human Chang Liver Cell Line
}

\author{
Benjamin I. Okeleye, ${ }^{1}$ Noxolo T. Mkwetshana, ${ }^{1}$ and Roland N. Ndip ${ }^{1,2}$ \\ ${ }^{1}$ Microbial Pathogenicity and Molecular Epidemiology Research Group, Department of Biochemistry \& Microbiology, \\ Faculty of Science and Agriculture, University of Fort Hare, Private Bag X1314, Alice 570, South Africa \\ ${ }^{2}$ Department of Microbiology and Parasitology, Faculty of Science, University of Buea, P.O. Box 63, Buea, Cameroon
}

Correspondence should be addressed to Roland N. Ndip; ndip3@yahoo.com

Received 3 January 2013; Accepted 28 January 2013

Academic Editors: J.-T. Cheng and P. Cos

Copyright (C) 2013 Benjamin I. Okeleye et al. This is an open access article distributed under the Creative Commons Attribution License, which permits unrestricted use, distribution, and reproduction in any medium, provided the original work is properly cited.

\begin{abstract}
We assessed the in vitro antimicrobial activity of Peltophorum africanum by means of the agar well and macrodilution methods. The toxicity on a normal human liver cell (Chang liver cell) was determined using the CellTiter-Blue cell viability assay, and the compounds contained in the fractions were identified using GC-MS. Zone diameter of inhibition of the extract ranged from $12.5 \pm$ 0.7 to $32 \pm 2.8 \mathrm{~mm}$ for bacteria and from $7.5 \pm 0.7$ to $26.4 \pm 3.4 \mathrm{~mm}$ for yeast. Marked activity of the extract was observed against Plesiomonas shigelloides ATCC 51903, with MIC and MLC values of 0.15625 and $0.3125 \mathrm{mg} / \mathrm{mL}$, respectively. The extract was both bactericidal $\left(\mathrm{MIC}_{\text {index }} \leq 2\right)$ and bacteriostatic/fungistatic $\left(\mathrm{MIC}_{\text {index }}>2\right)$ in activity. Lethal dose at $50\left(\mathrm{LD}_{50}\right)$ showed $82.64 \pm 1.40$ degree of toxicity at $24 \mathrm{hrs}$, and 95 percentile of cell death dose activity ranged from $\log 3.12 \pm 0.01$ to $4.59 \pm 0.03$. The activity of the eight fractions tested ranged from $1.0 \pm 0.5$ to $3.7 \pm 1.6 \mathrm{mg} / \mathrm{mL}\left(\mathrm{IC}_{50}\right)$ and from $2.1 \pm 0.8$ to $6.25 \pm 0 \mathrm{mg} / \mathrm{mL}\left(\mathrm{IC}_{90}\right)$. The extract was toxic to human Chang liver cell lines.
\end{abstract}

\section{Introduction}

Following the invention of modern medicine, herbal medicine suffered a setback, but recent advances in photochemistry and identification of plant compounds that are effective against life-threatening diseases have enhanced interest in it. In many developing countries, traditional medicine is one of the primary healthcare systems $[1,2]$. Extracts and bioactive compounds with known antimicrobial activities isolated from plants can be of great impact in the formulation of new drugs, and the potential of higher plants as source for new drugs is still largely unexplored [3]. The increasing prevalence of multidrug-resistant microbial strains due to indiscriminate use of broad-spectrum antibiotics, immunosuppressive agent, and continuous epidemics of HIV infection adds urgency to the search for alternative treatment. Most horrible human diseases are caused by bacteria, viruses, fungi, and parasitic worms [4]. Staphylococcus aureus, a
Gram-positive bacterium and an opportunistic pathogen of the human skin, has been incriminated in wound infection, toxic shock syndrome, and food poisoning [5], while Pseudomonas aeruginosa is a pathogen associated with pyogenic and urinary tract infections [6]. Plesiomonas shigelloides infections occur in the summer months and correlate with environmental contamination of freshwater and have been implicated in gastroenteritis [7]. Fungi especially Candida sp. and Cryptococcus sp. are increasingly being recognized as major pathogens in critically ill patients [8].

Peltophorum africanum (Sond Fabaceae), an African wattle (isiKhaba-mkhombe in Xhoza and Musese in Venda) is a semideciduous to deciduous trees, traditionally used in South Africa to alleviate gastric problems, human immunodeficiency virus/acquired immune deficiency syndrome (HIV/AIDS), and infertility [9]. Though the ethyl acetate extract of the stem bark of $P$. africanum has been previously investigated for its antimicrobial activity against clinical 
strains of Helicobacter pylori and other pathogens; [9] there is a dearth of information on its toxicity. This study was therefore aimed at elucidating the probable compounds responsible for the antimicrobial activity of the plant extract as well as evaluating its safety in an effort to validate its folkloric use in the treatment of microbial infections.

\section{Experimental Part}

2.1. Plant Extract. The ethyl acetate extract of the stem bark of $P$. africanum was selected based on the remarkable activity reported in our previous study [9]. The extract was prepared as described in our previous study with modifications. Briefly, dried powder of the stem bark ( $200 \mathrm{~g})$ was extracted with $96 \%$ ethyl acetate $(800 \mathrm{~mL})$ and filtered after $48 \mathrm{hrs}$. The plant residue was reextracted exhaustively (three filtration processes), and the filtrate was concentrated on a rotary evaporator (Strike 202 Steroglass, Italy) at $70^{\circ} \mathrm{C}$ to remove the ethyl acetate. Fresh working stock of the extract was prepared by sterilizing in $100 \%$ DMSO for each bioassay analysis. The extract was aseptically bottled using Acrodisc $25 \mathrm{~mm}$ PF Syringe (Pall, USA) and then tested for sterility by putting $0.5 \mathrm{~mL}$ of the extract into $2.5 \mathrm{~mL}$ of nutrient broth. A sterile extract was indicated by a clear broth (absence of turbidity) after incubation at $37^{\circ} \mathrm{C}$ for $24 \mathrm{hrs}$. The extracts were kept at $4^{\circ} \mathrm{C}$ until use.

2.2. Test Organisms. The microorganisms used were obtained from our microbial stock collection in the Department of Biochemistry and Microbiology University of Fort Hare, South Africa. The bacteria included Staphylococcus aureus NCTC 6571, Pseudomonas aeruginosa ATCC 15442, Plesiomonas shigelloides ATCC 51903, Helicobacter pylori ATCC 43526, Streptococcus pyogenes ATCC 49399, Aeromonas hydrophila ATCC 35654, Shigella sonnei ATCC 29930, and Salmonella Typhimurium ATCC 13311. The fungi included Aspergillus flavus ATCC 204304, Aspergillus niger ATCC 16888, Candida albicans ATCC 2091, and Cryptococcus neoformans ATCC 66031. All bacteria and fungi cultures were subcultured thrice for purity. The fungi were inoculated in Sabouraud dextrose broth and bacteria into nutrient broth (H. pylori was inoculated in brain heart infusion broth with Skirrow's supplement and 10\% horse serum) and incubated for $24 \mathrm{hrs}$ at $37^{\circ} \mathrm{C}(\mathrm{H}$. pylori was incubated microaerophilically in anaerobic jar with gas pack). The turbidity of the culture was adjusted with sterile saline solution to match $0.5 \mathrm{McF}$ arland standards.

2.3. Cell Line Growth and Maintenance. The human Chang liver cell line used in this study was a kind donation from Professor Maryna van de Venter of Nelson Mandela Metropolitan University, South Africa. Briefly, vials containing cells were taken from liquid nitrogen stocks. The cells were thawed in a water bath $\left(37^{\circ} \mathrm{C}\right)$ and transferred to a $25 \mathrm{~mm}^{3}$ culture flask (TPP, Switzerland). A $1 \mathrm{~mL}$ thawed cell stock was diluted with $9 \mathrm{~mL}$ prewarmed Dulbecco's Minimum Essential Medium (DMEM) containing 10\% fetal bovine serum (FBS). The cells were incubated in a $37^{\circ} \mathrm{C}$ humidified incubator
(Shel Lab, USA), $5 \% \mathrm{CO}_{2}$ for multiplication and adherence. Maintenance of cells was achieved by splitting the cells until the desired cell number and confluence was reached.

2.4. Antimicrobial Assay. The agar well diffusion method was used as previously described [10,11]. Agar plates were prepared using sterile brain heart infusion agar (Oxoid, England) with Skirrow's supplement and 10\% horse serum for H. pylori, Mueller-Hinton (MH) agar (Merck, Gauteng, South Africa) for bacteria and potato dextrose agar (PDA) (Lab M, UK) for fungi. Strains of standardized cultures were evenly spread onto the surface of the agar plates using sterile swab sticks. Wells were punched in the plates using a sterile stainless $6 \mathrm{~mm}$ cork borer. The wells were filled with $100 \mu \mathrm{L}$ of $25 \mathrm{mg} / \mathrm{mL}, 50 \mathrm{mg} / \mathrm{mL}$, and $100 \mathrm{mg} / \mathrm{mL}$ of the extract. Ten percent DMSO was used as a negative control and $30 \mu \mathrm{g} / \mathrm{mL}$ of amoxicillin and tetracycline as positive controls. Diffusion of the extracts, antibiotics, and DMSO was allowed at room temperature for 30 mins in a laminar flow cabinet and then incubated at $37^{\circ} \mathrm{C}$ (fungi, $27^{\circ} \mathrm{C}$ ) for 24-72 hrs. Each experiment was conducted in duplicate, and the zone diameters of inhibition (mean $\pm \mathrm{SD}$ ) produced by each of the concentrations of the solutions were measured in millimeters and interpreted according to the Clinical and Laboratory Standards Institute (CLSI) guideline [12].

2.5. Minimum Inhibitory Concentration (MIC) Determination. The MIC was determined according to the method of Delahaye et al. [13] with modification. Different concentrations $(0.005-10.0 \mathrm{mg} / \mathrm{mL})$ of the extract were prepared by twofold serial dilutions in brain heart infusion broth (Oxoid, England) with Skirrow's supplement and 10\% horse serum, Mueller-Hinton broth (Merck, Gauteng, South Africa) and sabouraud dextrose broth (Lab M, UK) for H. pylori, other bacterial strains, and fungi, respectively. Each tube was inoculated with $100 \mu \mathrm{L}$ of each of the adjusted microbial strain and incubated at $37^{\circ} \mathrm{C}$ (fungi, $27^{\circ} \mathrm{C}$ ) for $24-72 \mathrm{hrs}$. Tetracycline and amoxicillin $(30 \mu \mathrm{g} / \mathrm{mL})$ were used as positive controls, and two tubes each containing medium with/without a microbial strain and treatment were used as negative control. After the incubation period, the first tube in the series of concentrations that showed no visible trace of growth was taken as the MIC.

2.6. Minimum Lethal Concentration (MLC) Assay. Fresh nutrient agar (Merck, Gauteng, South Africa), PDA (Lab M, UK), and Columbia blood agar (Oxoid, England) plates prepared for bacteria, fungi, and $H$. pylori, respectively, were inoculated with one loopful of culture taken from each of the MIC tubes for the determination of minimum bactericidal concentration (MBC) and minimum fungicidal concentration (MFC). After the incubation periods, the lowest concentration of the extract that did not produce any or $>90 \%$ bacterial or fungal growth on the solid medium was regarded as the minimum lethal concentration (MLC) of the extract. The mechanism of antibiosis of the extracts was calculated using the ratio of MLC/MIC. When the ratio of 
TABLE 1: Antimicrobial susceptibility test of the ethyl acetate extract compared with standard antibiotics.

\begin{tabular}{|c|c|c|c|c|c|}
\hline \multirow{2}{*}{ Test bacteria and fungi } & $\mathrm{EAE}^{*}$ & EAE & EAE & Tetra. $^{*}$ & Amox.* \\
\hline & $25 \mathrm{mg} / \mathrm{mL}$ & $50 \mathrm{mg} / \mathrm{mL}$ & $100 \mathrm{mg} / \mathrm{mL}$ & $30 \mu \mathrm{g} / \mathrm{mL}$ & $30 \mu \mathrm{g} / \mathrm{mL}$ \\
\hline Helicobacter pylori (ATCC 43526) & $12.5 \pm 0.7$ & $14.25 \pm 0.4$ & $17.11 \pm 0.2$ & 0 & 0 \\
\hline Pseudomonas aeruginosa (ATCC 15442) & $16 \pm 1.4$ & $16.5 \pm 0.7$ & $18 \pm 1.4$ & $7.5 \pm 0.7$ & 0 \\
\hline Plesiomonas shigelloides (ATCC 51903) & $24.5 \pm 3.5$ & $26.5 \pm 2.1$ & $32 \pm 2.8$ & $26.7 \pm 2.3$ & 0 \\
\hline Streptococcus pyogenes (ATCC 49399) & $17.6 \pm 0.5$ & $19.9 \pm 1.2$ & $24.1 \pm 2.4$ & 0 & 0 \\
\hline Aeromonas hydrophila (ATCC 35654) & $17.5 \pm 0.7$ & $21.5 \pm 2.1$ & $24.9 \pm 2.8$ & $28.5 \pm 2.1$ & 0 \\
\hline Staphylococcus aureus (NCTC 6571) & $12.8 \pm 0.4$ & $20.7 \pm 0.4$ & $25.6 \pm 0.6$ & $27.1 \pm 1.3$ & 0 \\
\hline Shigella sonnei (ATCC 29930) & $18.6 \pm 0.9$ & $19.1 \pm 0.2$ & $21.9 \pm 1.2$ & 0 & 0 \\
\hline Salmonella Typhimurium (ATCC 13311) & $19.1 \pm 0.2$ & $21.5 \pm 2.1$ & $24.1 \pm 2.4$ & 0 & 0 \\
\hline Aspergillus flavus (ATCC 204304) & 0 & 0 & 0 & 0 & 0 \\
\hline Aspergillus niger (ATCC 16888) & 0 & 0 & 0 & 0 & 0 \\
\hline Candida albicans (ATCC 2091) & $16.9 \pm 0.2$ & $21.5 \pm 2.1$ & $26.4 \pm 3.4$ & $38.1 \pm 0.2$ & $36.9 \pm 1.7$ \\
\hline Cryptococcus neoformans (ATCC 66031) & $7.5 \pm 0.7$ & $12.5 \pm 0.7$ & $14.25 \pm 0.4$ & 0 & 0 \\
\hline
\end{tabular}

${ }^{*}$ EAE: ethyl acetate extract; Tetra.: tetracycline; Amox.: amoxicillin.

TABLE 2: Mechanism of antibiosis using MLC/MIC ${ }_{\text {index }}$ of the extract against test organisms.

\begin{tabular}{|c|c|c|c|c|c|}
\hline \multirow{2}{*}{ Test bacteria and yeast } & \multicolumn{3}{|c|}{ Ethyl acetate extract $(\mathrm{mg} / \mathrm{mL})$} & \multicolumn{2}{|c|}{ Tetracycline $(\mu \mathrm{g} / \mathrm{mL})$} \\
\hline & MIC $^{*}$ & MLC $^{*}$ & $\mathrm{MLC} \mathrm{MIC}_{\text {index }}$ & MIC & $\mathrm{MBC}^{*}$ \\
\hline Helicobacter pylori (ATCC 43526) & 2.5 & 10 & 4 & $\mathrm{ND}^{*}$ & $\mathrm{ND}$ \\
\hline Pseudomonas aeruginosa (ATCC 15442) & 0.625 & 1.25 & 2 & ND & ND \\
\hline Plesiomonas shigelloides (ATCC 51903) & 0.15625 & 0.3125 & 2 & 10 & $>10$ \\
\hline Streptococcus pyogenes (ATCC 49399) & 0.625 & 2.5 & 4 & ND & ND \\
\hline Aeromonas hydrophila (ATCC 35654) & 2.5 & 5 & 2 & 10 & $>10$ \\
\hline Staphylococcus aureus (NCTC 6571) & 2.5 & 5 & 2 & $>10$ & $>10$ \\
\hline Shigella sonnei (ATCC 29930) & 1.25 & 5 & 4 & ND & ND \\
\hline Salmonella Typhimurium (ATCC 13311) & 1.25 & 2.5 & 2 & ND & $\mathrm{ND}$ \\
\hline Candida albicans (ATCC 2091) & 5 & $>10$ & $>2$ & 10 & $>10$ \\
\hline Cryptococcus neoformans (ATCC 66031) & 10 & ND & ND & ND & ND \\
\hline
\end{tabular}

${ }^{*}$ MIC: minimum inhibitory concentration; MLC: minimum lethal concentration; MBC: minimum bactericidal concentration; ND: not determined.

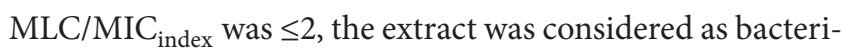
cidal/fungicidal otherwise as bacteriostatic/fungistatic. If the ratio was $\geq 16$ the extract was considered as ineffective $[13,14]$.

2.7. Assay for Cytotoxicity. Toxicity of the extract was evaluated on human Chang liver cell lines using microculture CellTiter-Blue viability (Promega, USA) assay [15]. For the assay, 96-well microplates were seeded with $100 \mu \mathrm{L}$ DMEM + high glucose, L-glutamine and sodium pyruvate (Thermo Sceintific, South Logan, Utah, USA) containing $3.0 \times 10^{3}$ cells in suspension and incubated in a $\mathrm{CO}_{2}$ incubator regulated at $37^{\circ} \mathrm{C}$ and $5 \% \mathrm{CO}_{2}$. After $24 \mathrm{hrs}$ incubation and attachment, the cells were treated with 1000, 500, 250, 125, 75, 25, and $5 \mu \mathrm{g} / \mathrm{mL}$ concentration of the extract. Exactly $60 \mu \mathrm{M}$ of curcumin (Sigma-Aldrich, South Africa) was used as positive control and 0.1\% DMSO as negative control. After 24, 48, and $72 \mathrm{hrs}$ of incubation, cell viability was determined by adding CellTiter-Blue as an indicator and further incubated for $4 \mathrm{hrs}$. Fluorescence was read at 570/620 nm using Analytical \& Diagnostic Product Gen spectrophotometer (BioTek, USA).
2.8. Fractionation of the Extract and Antimicrobial Activity of the Fractions. The ethyl acetate extract of $P$. africanum was fractionated using two solvent systems; toluene/ethanol (TEt; $90: 5$ ) and benzene/ethanol/ammonium hydroxide (BEtA; $90: 10: 1)$ using thin layer chromatography (TLC) and column chromatography methods $[16,17]$. The inhibitory effect of the fractions was carried out in accordance with our previously reported method [11]. Briefly, twofold dilutions of the fractions $(0.049-6.25 \mathrm{mg} / \mathrm{mL})$ were prepared in 96 -well plates containing brain heart infusion broth (Oxoid, England) with Skirrow's supplement and 10\% horse serum, MuellerHinton broth (Merck, Gauteng, South Africa), sabouraud dextrose broth (Lab M, UK) for H. pylori, other bacteria, and yeast cell, respectively. Exactly $25 \mu \mathrm{L}$ of each strain $(0.5$ McFarland standards) was added into the wells and the assay performed in duplicate. After incubation at $37^{\circ} \mathrm{C}$ for 24 hrs (bacteria) and $27^{\circ} \mathrm{C}$ for 3 days (yeast), the absorbance was read at $620 \mathrm{~nm}$ with Analytical \& Diagnostic Product Gen spectrophotometer (BioTek, USA). Concentration at which $50 \%\left(\mathrm{IC}_{50}\right)$ and $90 \%\left(\mathrm{IC}_{90}\right)$ of microbial growth were inhibited was determined. 
TABLE 3: Effective concentration and time interval on the percentage cell death.

\begin{tabular}{|c|c|c|c|c|c|c|}
\hline \multirow{2}{*}{ Percentile } & \multicolumn{3}{|c|}{ Probit } & \multicolumn{3}{|c|}{$\log (\text { dose })^{*}$} \\
\hline & $24 \mathrm{hrs}$ & $48 \mathrm{hrs}$ & $72 \mathrm{hrs}$ & $24 \mathrm{hrs}$ & $48 \mathrm{hrs}$ & $72 \mathrm{hrs}$ \\
\hline 5 & 3.36 & 3.36 & 3.36 & $-0.75 \pm 0.03$ & $0.76 \pm 0.01$ & $1.05 \pm 0.01$ \\
\hline 25 & 4.33 & 4.33 & 4.33 & $0.82 \pm 0.02$ & $1.58 \pm 0.01$ & $1.66 \pm 0.01$ \\
\hline 50 & 5.00 & 5.00 & 5.00 & $1.92 \pm 0.01$ & $2.15 \pm 0.00$ & $2.08 \pm 0.00$ \\
\hline 75 & 5.68 & 5.68 & 5.68 & $3.01 \pm 0.01$ & $2.72 \pm 0.01$ & $2.51 \pm 0.00$ \\
\hline 95 & 6.65 & 6.65 & 6.65 & $4.59 \pm 0.03$ & $3.54 \pm 0.01$ & $3.12 \pm 0.01$ \\
\hline
\end{tabular}

*Antilog which gives lethal dose in $\mu \mathrm{g} / \mathrm{mL}$. Probit analysis NCSS 2007 used to determine log (dose), percentile, and probit values.

TABLE 4: Lethal dose at 50 percent reduction of the cell population.

\begin{tabular}{lcccccccc}
\hline \multirow{2}{*}{ Dose $(\mu \mathrm{g} / \mathrm{mL})$} & \multicolumn{3}{c}{ Probit percent } & \multicolumn{3}{c}{ Actual percent* } & \multicolumn{2}{c}{$\mathrm{LD}_{50}(\mu \mathrm{g} / \mathrm{mL})^{*}$} \\
\hline 5 & $24 \mathrm{hrs}$ & $48 \mathrm{hrs}$ & $72 \mathrm{hrs}$ & $24 \mathrm{hrs}$ & $48 \mathrm{hrs}$ & $72 \mathrm{hrs}$ & $24 \mathrm{hrs}$ & $48 \mathrm{hrs}$ \\
25 & 25.24 & 4.34 & 1.37 & 19.23 & 3.87 & 5.21 & - & - \\
75 & 31.51 & 18.80 & 13.75 & 29.48 & 10.68 & 5.34 & - & - \\
125 & 38.36 & 37.41 & 37.02 & 34.96 & 24.65 & 16.96 & $82.64 \pm 1.40$ & - \\
250 & 45.59 & 47.66 & 50.88 & 55.96 & 65.03 & 70.68 & - & $140.09 \pm 1.33$ \\
500 & 51.03 & 61.70 & 69.21 & 60.12 & 71.17 & 79.41 & - & - \\
1000 & 62.54 & 74.33 & 83.68 & 61.85 & 72.16 & 82.88 & - & - \\
\hline
\end{tabular}

${ }^{*} \mathrm{LD}_{50}$ (50\% of the cells have been killed); actual and probit percents were calculated using probit statistical analysis software "NCSS 2007 "; actual $\%=$ actual formulas ( $n$ is the number of cells in a group); -: not applicable.

2.9. GC-MS Analysis for the Identification of Compounds in the Fractions. The fractions were dissolved and injected onto a GC column and helium was used as the carrier gas with injection volume of $1 \mu \mathrm{L}$. Injection temperature and MS transfer were set at $280^{\circ} \mathrm{C}$ with acquisition mode scanning mass range of 40 to $550 \mathrm{~m} / \mathrm{z}$ (electron ionization at $70 \mathrm{Ev}$ ). Agilent 6890N GC with CTC Combi-PAL Autosampler and Agilent 5975B MS with Rtx-5MS (30 m, 0.25 mm ID, $0.5 \mu \mathrm{m}$ film thickness) Restek 12723-127 were used for the analysis [18].

Ethical Consideration. This study which is a continuation of our line of studies on microbial pathogens and anti-infective from medicinal plants had been approved by the institutional review board of the University of Fort Hare.

\section{Results}

3.1. Susceptibility and Resistant Phenotype. The ethyl acetate extract of $P$. africanum was tested against pathogenic bacteria, yeast, and mold in this study. All the eight bacteria and two yeast tested were susceptible at the three concentrations of 25,50 , and $100 \mathrm{mg} / \mathrm{mL}$, with the zone diameter of inhibition ranging from $12.5 \pm 0.7$ to $32 \pm 2.8 \mathrm{~mm}$. For yeast, it ranged from $7.5 \pm 0.7$ to $26.4 \pm 3.4 \mathrm{~mm}$, while, for mold, no activity was observed. Helicobacter pylori ATCC 43526, Streptococcus pyogenes ATCC 49399, Shigella sonnei ATCC 29930, Salmonella Typhimurium ATCC 13311, Aspergillus flavus ATCC 204304, Aspergillus niger ATCC 16888, and Cryptococcus neoformans ATCC 66031 were resistant against tetracycline (positive control antibiotic) at $30 \mu \mathrm{g} / \mathrm{mL}$ (Table 1).
3.2. Mechanism of Antibiosis. The extract had bactericidal effect (MLC/MIC index $\leq 2)$ on $P$. aeruginosa, $P$. shigelloides, A. hydrophila, S. aureus, and S. Typhimurium. Bacteriostatic/fungistatic effect $\left(\mathrm{MLC} / \mathrm{MIC}_{\text {index }}>2\right)$ was noted against $H$. pylori, S. pyogenes, S. sonnei, and C. albicans. Marked activity was observed against $P$. shigelloides with MIC and MLC values of 0.15625 and $0.3125 \mathrm{mg} / \mathrm{mL}$, respectively (Table 2).

3.3. Cytotoxicity Effect. We observed that at 5, 25, 50, 75, and 95 percentile of cell death after 24, 48, and $72 \mathrm{hrs}$ of incubation, the extract dose activity ranged from log to $0.75 \pm$ $0.03-1.05 \pm 0.01,0.82 \pm 0.02$ to $1.66 \pm 0.01,1.92 \pm 0.01$ to $2.15 \pm 0.00,2.51 \pm 0.00$ to $3.01 \pm 0.01$, and $3.12 \pm 0.01$ to $4.59 \pm 0.03$, respectively (Table 3$)$. Lethal dose at $50\left(\mathrm{LD}_{50}\right)$ showed $82.64 \pm 1.40,140.09 \pm 1.33$, and $121.07 \pm 0.92 \mu \mathrm{g} / \mathrm{mL}$ degree of toxicity at 24, 48 and 72 hrs, respectively (Table 4).

3.4. In Vitro Antimicrobial Activity of the Fractions from the Ethyl Acetate Extract of P. africanum. Activity of the fractions on the bacteria and yeast cells are shown in Table 5. Fractions BEtA2, BEtA4, T1, and BEtA3 inhibited $50 \%$ of test organisms $\left(\mathrm{IC}_{50}\right)$ at $1.0 \pm 0.5,1.0 \pm 0.6,1.6 \pm 1.7$, and $1.7 \pm 0.9(\mathrm{mg} / \mathrm{mL})$, meanwhile $90 \%$ were inhibited $\left(\mathrm{IC}_{90}\right)$ at $2.5 \pm 0.8,3.1 \pm 2.3$, $2.1 \pm 0.8$, and $3.8 \pm 1.9(\mathrm{mg} / \mathrm{mL})$, respectively. Of the four fractions, the best activity against yeast ( $C$. albicans) was demonstrated by BEtA4 with $\mathrm{IC}_{50}$ and $\mathrm{IC}_{90}$ values of 0.391 and $1.563 \mathrm{mg} / \mathrm{mL}$, respectively, while for the bacteria, the same fraction exhibited marked activity against $P$. aeruginosa with $\mathrm{IC}_{50}$ and $\mathrm{IC}_{90}$ of 0.024 and $0.097 \mathrm{mg} / \mathrm{mL}$, respectively. 
TABLE 5: Inhibitory concentration $\left(\mathrm{IC}_{50} \&_{90}\right)$ of the eight isolated bioactive fractions $(\mathrm{mg} / \mathrm{mL})$.

\begin{tabular}{|c|c|c|c|c|c|c|c|c|}
\hline Bacteria/yeast & $\mathrm{T} 1$ & $\mathrm{~T} 2$ & TEt1 & TEt9 & TEt10 & BEtA2 & BEtA3 & BEtA4 \\
\hline \multicolumn{9}{|l|}{ A. hydrophila } \\
\hline $\mathrm{IC}_{50}$ & 0.391 & 3.125 & 3.125 & 1.563 & 1.563 & 1.563 & 1.563 & 1.563 \\
\hline $\mathrm{IC}_{90}$ & 1.563 & $\mathrm{ND}^{*}$ & ND & 3.125 & 3.125 & 3.125 & 3.125 & 3.125 \\
\hline \multicolumn{9}{|l|}{ H. pylori } \\
\hline $\mathrm{IC}_{50}$ & 6.25 & 3.125 & 6.25 & 3.125 & 6.25 & 1.563 & ND & 1.563 \\
\hline $\mathrm{IC}_{90}$ & ND & ND & ND & ND & ND & 3.125 & ND & 3.125 \\
\hline \multicolumn{9}{|l|}{ P. aeruginosa } \\
\hline $\mathrm{IC}_{50}$ & 1.563 & 3.125 & 3.125 & 3.125 & 1.563 & 0.781 & 1.563 & 0.024 \\
\hline $\mathrm{IC}_{90}$ & ND & ND & ND & ND & 6.25 & 1.563 & 3.125 & 0.097 \\
\hline \multicolumn{9}{|l|}{ P. shigelloides } \\
\hline $\mathrm{IC}_{50}$ & 1.563 & 3.125 & 3.125 & 3.125 & 3.125 & 1.563 & 1.563 & 0.781 \\
\hline $\mathrm{IC}_{90}$ & 3.125 & ND & $\mathrm{ND}$ & ND & ND & 3.125 & 6.25 & 1.563 \\
\hline \multicolumn{9}{|l|}{ S. aureus } \\
\hline $\mathrm{IC}_{50}$ & 0.781 & 3.125 & 3.125 & 1.563 & 1.563 & 0.781 & 0.781 & 0.781 \\
\hline $\mathrm{IC}_{90}$ & 1.563 & 6.25 & 6.25 & 3.125 & 3.125 & 3.125 & 1.563 & 6.25 \\
\hline \multicolumn{9}{|l|}{ S. pyogenes } \\
\hline $\mathrm{IC}_{50}$ & 0.781 & 3.125 & 1.563 & 3.125 & 3.125 & 0.781 & 1.563 & 0.391 \\
\hline $\mathrm{IC}_{90}$ & 3.125 & ND & 6.25 & ND & ND & 1.563 & 3.125 & 1.563 \\
\hline \multicolumn{9}{|l|}{ S. sonnei } \\
\hline $\mathrm{IC}_{50}$ & 0.781 & 3.125 & 3.125 & 1.563 & 1.563 & 0.391 & 1.563 & 1.563 \\
\hline $\mathrm{IC}_{90}$ & 1.563 & ND & ND & 3.125 & ND & 1.563 & 3.125 & 6.25 \\
\hline \multicolumn{9}{|c|}{ S. Typhimurium } \\
\hline $\mathrm{IC}_{50}$ & 0.391 & 3.125 & 3.125 & 1.563 & 3.125 & 0.781 & 3.125 & 1.563 \\
\hline $\mathrm{IC}_{90}$ & 1.563 & ND & ND & 3.125 & ND & 3.125 & 6.25 & 1.563 \\
\hline \multicolumn{9}{|l|}{ C. albicans } \\
\hline $\mathrm{IC}_{50}$ & 1.563 & 3.125 & ND & 0.781 & 1.563 & 0.781 & 0.781 & 0.391 \\
\hline $\mathrm{IC}_{90}$ & ND & 6.25 & ND & 6.25 & ND & 1.563 & 1.563 & 1.563 \\
\hline \multicolumn{9}{|l|}{ C. neoformans } \\
\hline $\mathrm{IC}_{50}$ & 1.563 & 3.125 & 6.25 & 1.563 & ND & 1.563 & 3.125 & 1.563 \\
\hline $\mathrm{IC}_{90}$ & $\mathrm{ND}$ & ND & ND & 3.125 & ND & 3.125 & 6.25 & 6.25 \\
\hline $\mathrm{IC}_{50}$ & $1.6 \pm 1.7$ & $3.125 \pm 0$ & $3.7 \pm 1.6$ & $2.1 \pm 0.9$ & $2.6 \pm 1.6$ & $1.0 \pm 0.5$ & $1.7 \pm 0.9$ & $1.0 \pm 0.6$ \\
\hline $\mathrm{IC}_{90}$ & $2.1 \pm 0.8$ & $6.25 \pm 0$ & $6.25 \pm 0$ & $3.7 \pm 1.3$ & $4.2 \pm 1.8$ & $2.5 \pm 0.8$ & $3.8 \pm 1.9$ & $3.1 \pm 2.3$ \\
\hline
\end{tabular}

*ND: not determined.

3.5. Identified Compounds in the Fractions of Ethyl Acetate Extract of P. africanum. Though we proceeded to determine the possible compounds responsible for the observed activities in these fractions, Table 6 gives only the compounds identified in BEtA4, which had the best activity. However, volatile compounds identified in the fractions are those mostly found in food and medicine which are grouped into family of compounds such as hydrocarbon (cholest-2eno[3,2-a]naphthalene, $\quad 4^{\prime}$-dimethylamino; $0.2 \% \quad \mathrm{TP}$; BEtA3), alcohol (9-O-pivaloyl-N-acetylcolchinol; 17\% TP; TEt1), carbonyls (6-phenylamino- $1 \mathrm{H}$-pyrimidine-2,4-dione; 2.7\% TP; BEtA3), acids (isopimaric acid TMS; $0.1 \% \mathrm{TP}$; BEtA2), esters (stig-masta-5,22-dien-3-ol, acetate, (3.beta., 22Z); 0.8\% TP; T1), ethers (1-monolinoleoylglycerol trimethylsilyl ether, 2.1\% TP, BEtA3; beta.-Sitosterol trimethylsilyl ether, $8.8 \%$ TP, BEtA2), acetals (cyclic 3,23-acetal with acetone, $0.2 \%$ TP, BEtA2; 3,4-dimethyl-1-dimethyl (allyl)-silyloxycyclohexane, 0.9\% TP, BEtA3), halogens (3bromomethyl-3,6,6-trimethyl-cyclo-hexene; $2.6 \%$ TP; T2), amides (N-methyl-1-adamantaneac- etamide; 3.4\% TP; TEt10), phenols (phenol, 4-chloro-6-iodo-2-(4-iodophenyliminomethyl) and silane, trimethyl[5-methyl-2-(1-methylethyl)phenoxy]; 0.9\% TP; BEtA3), bases (19-Norpregna-1, 3,5(10)-trien-20-yn-2-amine, 3,17-bis[(trimethylsilyl)oxy], (17.alpha.); 1.8\% TP; BEtA4), ketones (1-(2-naphthyloxy)4-nitroanthraquinone; $0.2 \% \mathrm{TP}$; BEtA2), furans (fructofuranosyl 2,3,4,6-tetrakis-O-(trimethylsilyl), 3.4\% TP, T2; Furan, 2-(diphenylamino)-4-(morpholinocar- bonyl)-5-(pnitrophenyl), 1\% TP, BEtA3 and BEtA2 (1.3\% TP)), coumarins (2H-1,3-dithiolo[4,5-c] coumarine, 2-dicyanomethylene-8nitro; $0.4 \%$ TP; BEtA3), and sulfur compounds (2-(4-methoxy-phenyl)-7-oxo-7H-[1,2,4] triazolo[5,1-b][1,3]thiazine5-carboxylic acid, methyl ester; $0.3 \%$ TP; BEtA3) (Table 6 and Figure 1). 
TABLE 6: Identified compounds (twenty) from the BEtA4 fraction and their total percentage present.

\begin{tabular}{|c|c|c|c|c|}
\hline \multicolumn{5}{|c|}{ BEtA4 } \\
\hline PK & RT & NIST05 library identified compounds & QM & $\mathrm{TP}(\%)$ \\
\hline 1 & 7.2866 & Benzoic acid, 3-methoxy-4-[(trimethylsilyl)oxy], trimethylsilyl ester & 96 & 6.9 \\
\hline 2 & 7.5432 & Azelaic acid, bis(trimethylsilyl) ester & 74 & 0.8 \\
\hline 3 & 8.5248 & Trimethylsilyl 3,5-dimethoxy-4-(trimethylsilyloxy)benzoate & 99 & 2.0 \\
\hline 4 & 8.7557 & Cinnamic acid, 4-methoxy-3-(trimethylsiloxy), trimethylsilyl ester & 99 & 1.5 \\
\hline 5 & 9.9169 & Hexadecanoic acid, trimethylsilyl ester & 96 & 1.7 \\
\hline 6 & 10.3852 & Ferulic acid, trimethylsiloxy, trimethylsilyl ester & 99 & 2.9 \\
\hline 7 & 11.6811 & Octadecanoic acid, trimethylsilyl ester & 99 & 1.2 \\
\hline 8 & 13.6057 & Unknown & 46 & 2.8 \\
\hline 10 & 14.8823 & Unknown & 50 & 9.8 \\
\hline 11 & 15.5816 & Lanost-8-en-3-one & 15 & 0.4 \\
\hline 12 & 16.2937 & Tetracosanoic acid, trimethylsilyl ester & 98 & 10.7 \\
\hline 13 & 16.6978 & 3-Oxo-9b-lanosta-7-en-26,23-olide & 35 & 0.9 \\
\hline 14 & 16.9609 & Hexacosanoic acid, 2-[(trimethylsilyl)oxy], trimethylsilyl ester & 22 & 2.6 \\
\hline 15 & 17.6345 & Lanosta-9(11),24-dien-3-ol, acetate, (3.beta.) & 27 & 15.4 \\
\hline 17 & 17.8911 & 19-Norpregna-1,3,5(10)-trien-20-yn-2-amine,3,17-bis[(trimethylsilyl)oxy], (17.alpha.) & 43 & 1.8 \\
\hline 18 & 18.2696 & Unknown & 38 & 1.9 \\
\hline 21 & 18.9047 & Unknown & 3 & 9.8 \\
\hline 28 & 22.0354 & Hop-22(29)-en-3.beta.-ol & 70 & 11.0 \\
\hline 29 & 22.6577 & Unknown & 35 & 2.8 \\
\hline 30 & 25.1853 & Unknown & 38 & 4.1 \\
\hline
\end{tabular}

${ }^{*}$ PK: peak; RT: retention time; QM: quality march; TP: total percentage.

\section{Discussion}

Resistance of microorganisms to currently available antimicrobial agents used in the treatment of infectious diseases requires new assessment. The antimicrobial susceptibility observed in the current study was concentration dependent. For example, $24.5 \pm 3.5,26.5 \pm 2.1$, and $32 \pm 2.8 \mathrm{~mm}$ zones of inhibition were observed for $P$. shigelloides and $16.9 \pm 0.2$, $21.5 \pm 2.1$, and $26.4 \pm 3.4 \mathrm{~mm}$ for $C$. albicans at 25,50 , and $100 \mathrm{mg} / \mathrm{mL}$ concentration of the extract, respectively. This is similar to the observation reported in our previous study of this extract against clinical strains of $H$. pylori [9]. Some of the bacteria and fungi species on the other hand were resistant to tetracycline. The incessant spread of multidrug-resistant pathogens has become a serious threat and a major public health concern worldwide, leading to the re-emergence of previously controlled diseases, which contributes extensively to the high incidence of opportunistic and chronic infection cases all over the world $[3,8,10,11]$.

The extract had MIC and MLC values of 0.15625 and $0.3125 \mathrm{mg} / \mathrm{mL}$, respectively, against $P$. shigelloides, a Gramnegative bacterium that causes gastroenteritis. $P$. shigelloides has mostly been isolated from freshwater fish, shell fish, cattles, goats, swine, cats, dogs, monkeys, and snakes; and shares similar antigens with $S$. sonnei which has been implicated in dysentery [19]. Salmonella Typhimurium mostly found in the intestinal lumen has been etiologically linked to diarrhea and typhoid fever, while $H$. pylori is a major risk factor in peptic ulcer, gastritis, and gastric cancer in later life [9, 20,21]. There was no discrepancy of activity observed with the extract in both Gram-negative and -positive (S. pyogenes and S. aureus) bacteria in the current study, an interesting finding which points to the fact that this plant could be used in the treatment of gastrointestinal related and other morbidities.

The mechanism of antibiosis revealed that the extract was bacteriostatic/fungistatic against 3 organisms, bactericidal against 5 , and was not considered ineffective against any of the organisms tested in our study $\left(\mathrm{MLC} / \mathrm{MIC}_{\text {index }} \geq 16\right.$ ). Fractions BEtA2, BEtA4, T1, and BEtA3 inhibited $90 \%$ of the test organisms $\left(\mathrm{IC}_{90}\right)$ at $2.5 \pm 0.8,3.1 \pm 2.3,2.1 \pm 0.8$, and $3.8 \pm 1.9(\mathrm{mg} / \mathrm{mL})$, respectively. Although it might seem reasonable that bactericidal drugs would have a preference to bacteriostatic drugs, the nature of infection is important in deciding which kind of drug to apply. For example, high concentrations of some bacteriostatic agents are also bactericidal, while low concentrations of some bactericidal agents are bacteriostatic [22]. Furthermore, in central nervous system infections, a bactericidal drug can discharge bacterial products that stimulate inflammation. Certain bacteriostatic drugs may be ideal in cases of streptococcal and clostridial gangrene, since they inhibit the production of the toxins that cause a great deal of the morbidity $[13,14,22]$.

Although there is a dearth of information in the literature on the microbial and cytotoxic effect of the ethyl acetate extract of the stem bark of $P$. africanum, other solvents extract (methanol, acetone, dichloromethane hexane etc.) and plant parts have been reported to be active against some 
TIC: T2.D \data.ms

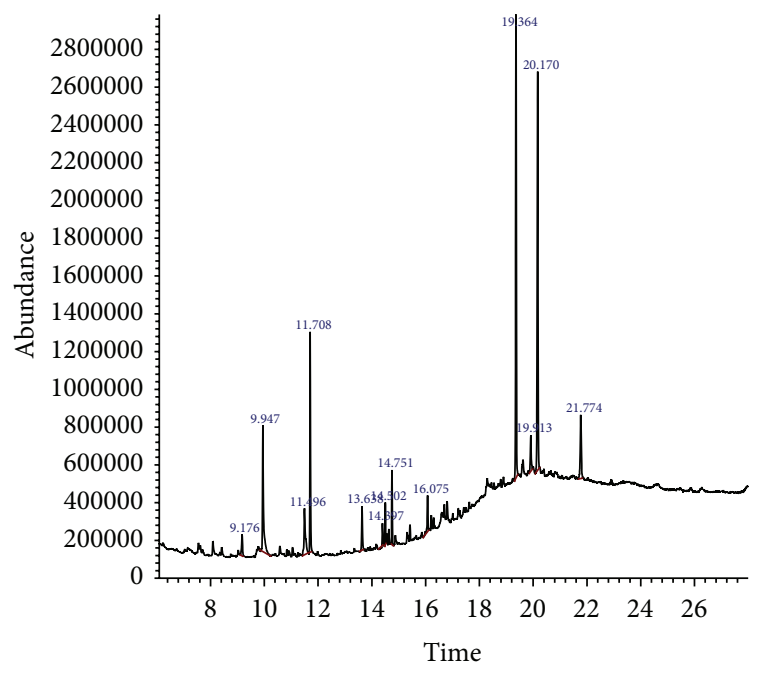

(a)

TIC: BEtA2_1.D \data.ms

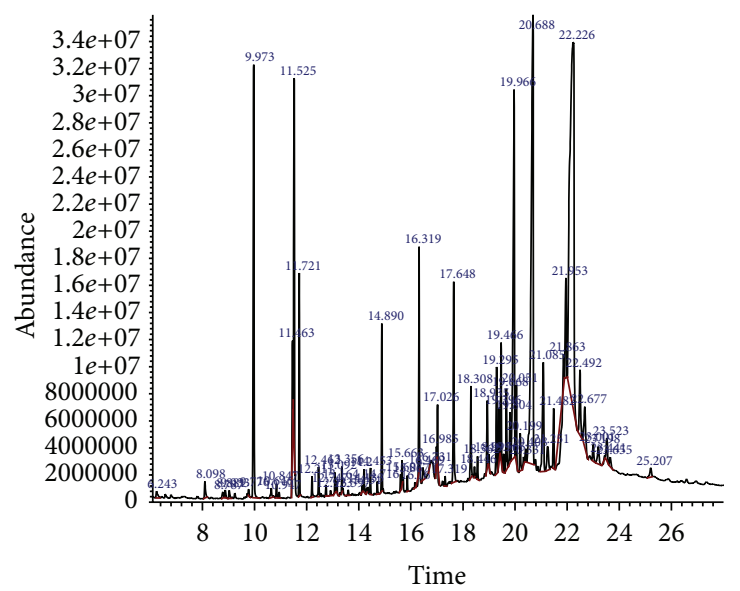

(c)

TIC: TEt1.D \data.ms

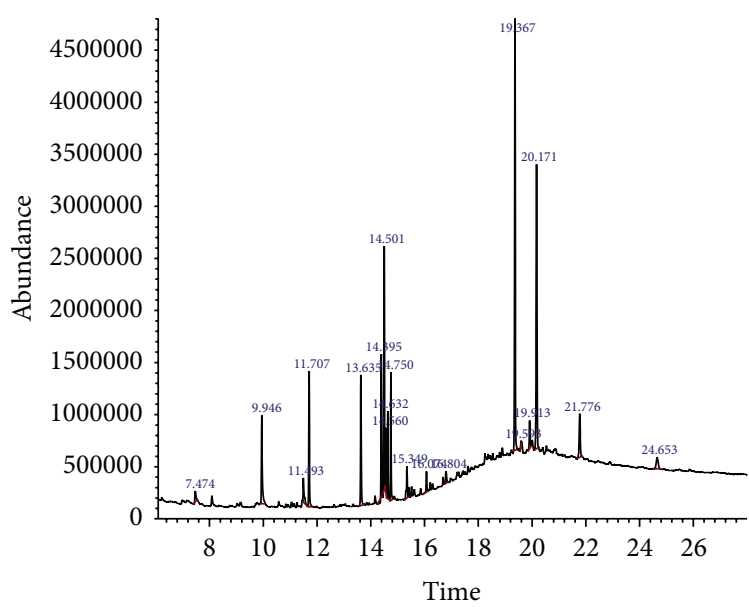

(e)
TIC: BEtA3.D \data.ms

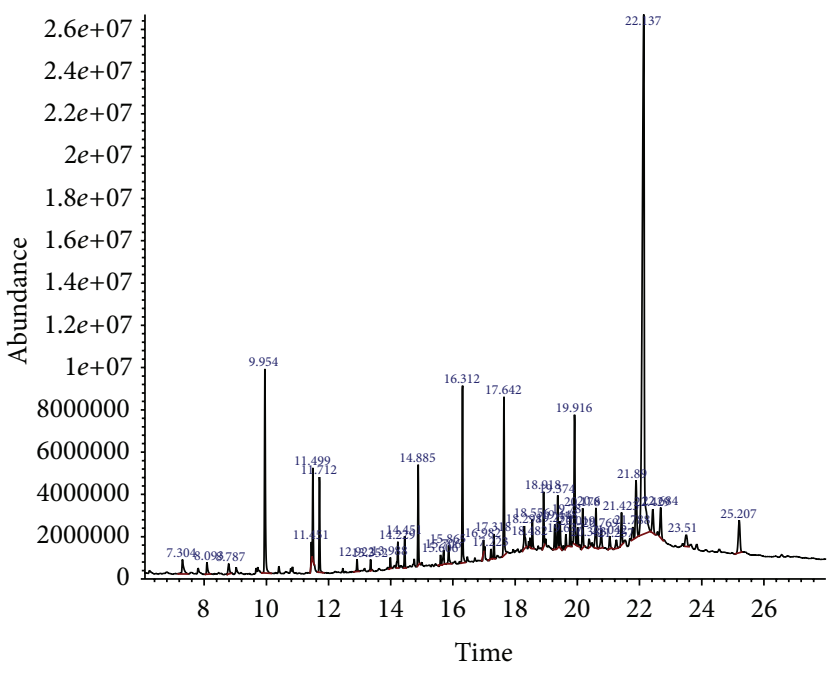

(b)

TIC: TEt10.D \data.ms

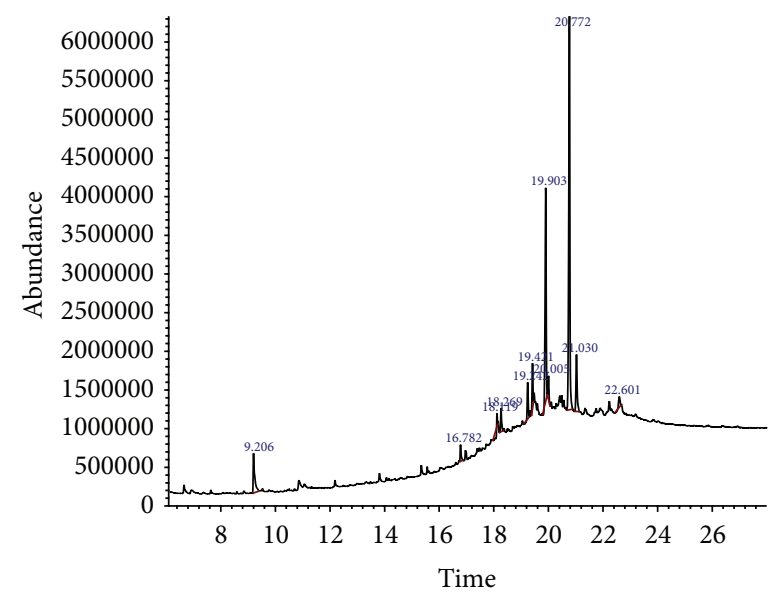

(d)

TIC: T1.D $\backslash$ data.ms

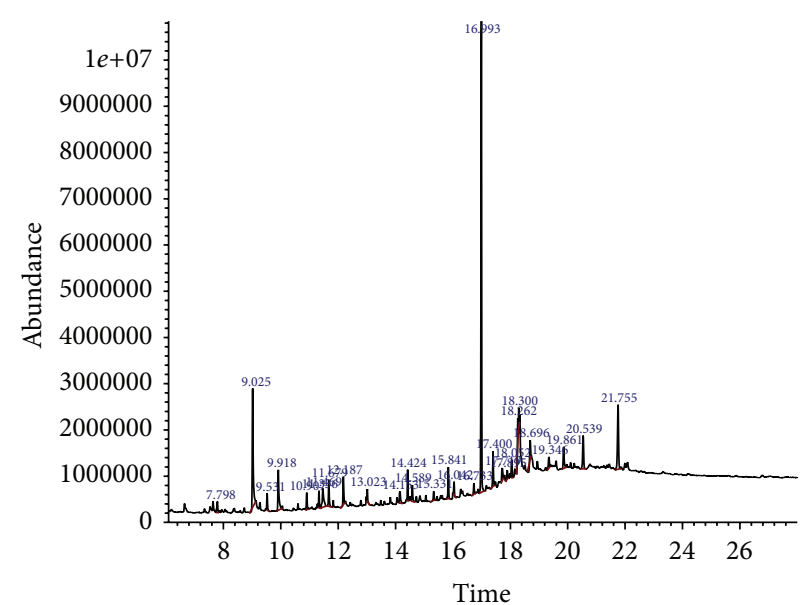

(f)

Figure 1: Continued. 


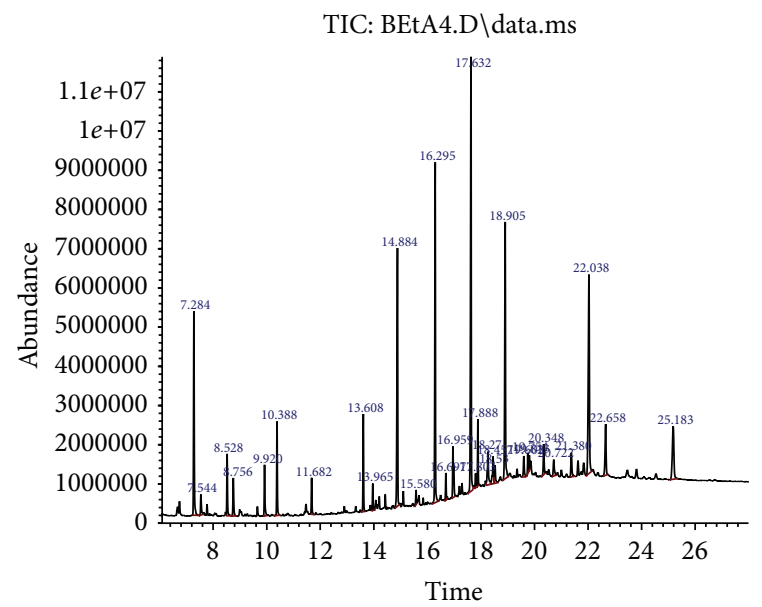

(g)
TIC: TEt9.D \data.ms

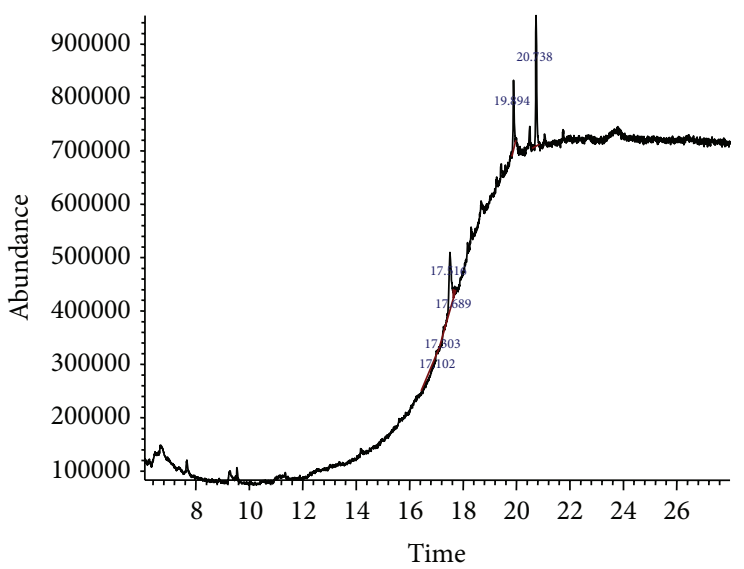

(h)

FIGURE 1: GC-MS total ion chromatogram (TIC) showing the retention time of the compounds identified from the fractions.

bacteria including Campylobacter spp., Enterococcus fecalis, Staphylococcus aureus, Escherichia coli, Proteus mirabilis, and Helicobacter pylori $[9,23,24]$. However, the effect of a drug on an organism is complex and involves interactions at multiple levels that cannot be predicted using biochemical assays. To understand this complexity, increase use of cell-based screening assays as more biologically relevant surrogates are being employed to predict the response of the organism. Moreover, in the drug discovery process, predicting cellular toxicity is essential and eukaryotic cell culture has been recognized as the model system of choice to get an approximation of toxicity [25].

The $\mathrm{LD}_{50}$ (lethal dose, 50\%) indicates the quantity of extracts/compounds/drugs that, if administered to a population of organisms, will cause $50 \%$ of the organisms to perish. A high $\mathrm{LD}_{50}$ implies it would take a large quantity of the extract to cause a toxic response, while small $\mathrm{LD}_{50}$ values are highly toxic and could be dangerous. It was observed that the dose of the extract appeared to be more toxic after $24 \mathrm{hrs}$ (log $\left.1.92 \pm 0.01 ; \mathrm{LD}_{50}=82.64 \pm 1.40\right)$ of treatment than at $48(\mathrm{log}$ $\left.2.15 \pm 0.00 ; \mathrm{LD}_{50}=140.09 \pm 1.33\right)$ and $72 \mathrm{hrs}\left(2.08 \pm 0.00 ; \mathrm{LD}_{50}\right.$ $=121.07 \pm 0.92)$. Cell-based lethality assay is an indication of cytotoxicity, bactericidal and fungicidal activities, pesticidal effects, and various pharmacologic actions. The $\mathrm{LD}_{50}$ value obtained in the current study indicates that the extract has high pharmacological actions $[26,27]$. The activity observed against bacteria, fungi, and human Chang liver cell may be ascribed to the compounds identified in the fractions of the extract. For example, phytosterols (e.g., silane,[[(3.beta.,24R)ergost-5-en-3-yl] oxy]trimethyl) are recognized as save ingredients that lower blood cholesterol [28]. Gallic acid, [(benzoic acid, 3,4,5-tris(trimethylsiloxy), trimethylsilyl)] is a phenolic compound that helps to protect human cells against oxidative damage and cancer [29]. Lupeol, ferulic acid, and Hop-22(29)-en-3.beta.-ol acts as an antioxidant, antiinflammatory, and antiulcerogenic agent [30].

\section{Conclusions}

The ethyl acetate extract of $P$. africanum exhibited in vitro antibacterial (both Gram-negative and positive species) and antifungal activity. The major chemical compounds revealed by GC-MS analysis are believed to be responsible for the antimicrobial activity. However, since the extracts were toxic to the human Chang liver cells, we recommend that this plant extract should be used with caution, and further studies using in vivo (animal model) approach should be conducted to confirm this finding.

\section{Conflict of Interests}

The authors declare no conflict of interests.

\section{Acknowledgments}

Sincere gratitude is due to the National Research Foundation, South Africa (Grant no. CSUR2008052900010) and the Govan Mbeki Research and Development Centre, University of Fort Hare, South Africa, for funding.

\section{References}

[1] N. R. Farnsworth, "Ethnopharmacology and future drug development: the North American experience," Journal of Ethnopharmacology, vol. 38, no. 2-3, pp. 145-152, 1993.

[2] P. J. Houghton, "The role of plants in traditional medicine and current therapy," Journal of Alternative and Complementary Medicine, vol. 1, no. 2, pp. 131-143, 1995.

[3] S. Satish, M. P. Raghavendra, and K. A. Raveesha, "Evaluation of antibacterial potential of some plants against human pathogenic bacteria," Advances in Biological Research, vol. 2, no. 3-4, pp. 4448, 2008.

[4] B. Mahesh and S. Satish, "Antimicrobial activity of some important medicinal plant against plant and human pathogens," World Journal of Agricultural Sciences, vol. 4, pp. 839-843, 2008. 
[5] L. Halcón and K. Milkus, "Staphylococcus aureus and wounds: a review of tea tree oil as a promising antimicrobial," The American Journal of Infection Control, vol. 32, no. 7, pp. 402408, 2004.

[6] A. Kumar, A. Kumar, P. Thakur et al., "Antibacterial activity of green tea (Camellia sinensis) extracts against various bacteria isolated from environmental sources," Recent Research in Science and Technology, vol. 4, no. 1, pp. 19-23, 2012.

[7] K. Krovacek, L. M. Eriksson, C. González-Rey, J. Rosinsky, and I. Ciznar, "Isolation, biochemical and serological characterisation of Plesiomonas shigelloides from freshwater in Northern Europe," Comparative Immunology, Microbiology and Infectious Diseases, vol. 23, no. 1, pp. 45-51, 2000.

[8] M. Alka, A. Shrivastava, and S. K. Jain, "Screening of some plant extracts against Alternaria sp. isolated from foot infections in cancer patients," International Journal of PharmTech Research, vol. 2, no. 2, pp. 1165-1170, 2010.

[9] B. I. Okeleye, A. Samie, P. O. Bessong et al., "Crude ethyl acetate extract of the stem bark of Peltophorum africanum (Sond, Fabaceae) possessing in vitro inhibitory and bactericidal activity against clinical isolates of Helicobacter pylori," Journal of Medicinal Plants Research, vol. 4, no. 14, pp. 1432-1440, 2010.

[10] R. N. Ndip, A. E. M. Tarkang, S. M. Mbullah et al., "In vitro anti-Helicobacter pylori activity of extracts of selected medicinal plants from North West Cameroon," Journal of Ethnopharmacology, vol. 114, no. 3, pp. 452-457, 2007.

[11] B. I. Okeleye, P. O. Bessong, and R. N. Ndip, "Preliminary phytochemical screening and in vitro anti-Helicobacter pylori activity of extracts of the stem bark of Bridelia micrantha (Hochst., Baill., Euphorbiaceae)," Molecules, vol. 16, no. 8, pp. 6193-6205, 2011.

[12] M. A. Wikler, "Performance standards for antimicrobial susceptibility testing, eighteenth informational supplement M100S18," Clinical and Laboratory Standards Institute, vol. 28, no. 1, pp. 46-52, 2008.

[13] C. Delahaye, L. Rainford, A. Nicholson, S. Mitchell, J. Lindo, and M. Ahmad, "Antibacterial and antifungal analysis of crude extracts from the leaves of Callistemon viminalis," Journal of Medical and Biological Sciences, vol. 3, no. 1, pp. 1-7, 2009.

[14] S. Shanmughapriya, A. Manilal, S. Sujith, J. Selvin, G. S. Kiran, and K. Natarajaseenivasan, "Antimicrobial activity of seaweeds extracts against multiresistant pathogens," Annals of Microbiology, vol. 58, no. 3, pp. 535-541, 2008.

[15] N. Merghoub, L. Benbacer, S. Amzazi, H. Morjani, and M. El Mzibri, "Cytotoxic effect of some Moroccan medicinal plant extracts on human cervical cell lines," Journal of Medicinal Plant Research, vol. 3, no. 12, pp. 1045-1050, 2009.

[16] T. Yrjönen, L. Peiwu, J. Summanen, A. Hopia, and H. Vuorela, "Free radical-scavenging activity of phenolics by reversedphase TLC, Journal of the American Oil Chemists' Society, vol. 80, no. 1, pp. 9-14, 2003.

[17] P. Masoko and J. N. Eloff, "Bioautography indicates the multiplicity of antifungal compounds from twenty-four Southern African Combretum species (Combretaceae)," African Journal of Biotechnology, vol. 5, no. 18, pp. 1625-1647, 2006.

[18] P. R. Adams, Identification of Essential Oil Components by Ion Trap Mass Spectroscopy, Academic Press, New York, NY, USA, 1989.

[19] T. Niedziela, J. Lukasiewicz, W. Jachymek, M. Dzieciatkowska, C. Lugowski, and L. Kenne, "Core oligosaccharides of Plesiomonas shigelloides O54:H2 (Strain CNCTC 113/92): structural and serological analysis of the lipopolysaccharide core region, the $\mathrm{O}$-antigen biological repeating unit, and the linkage between them," The Journal of Biological Chemistry, vol. 277, no. 14, pp. 11653-11663, 2002.

[20] E. A. Miao and S. I. Miller, "A conserved amino acid sequence directing intracellular type III secretion by Salmonella typhimurium," Proceedings of the National Academy of Sciences of the United States of America, vol. 97, no. 13, pp. 7539-7544, 2000.

[21] N. F. Tanih, B. I. Okeleye, L. M. Ndip et al., "Helicobacter pylori prevalence in dyspeptic patients in the Eastern Cape Provincerace and disease status," South African Medical Journal, vol. 100, no. 11, pp. 734-737, 2010.

[22] G. A. Pankey and L. D. Sabath, "Clinical relevance of bacteriostatic versus bactericidal mechanisms of action in the treatment of gram-positive bacterial infections," Clinical Infectious Diseases, vol. 38, no. 6, pp. 864-870, 2004.

[23] A. Samie, C. L. Obi, P. O. Bessong, and L. Namrita, "Activity profiles of fourteen selected medicinal plants from Rural Venda communities in South Africa against fifteen clinical bacterial species," African Journal of Biotechnology, vol. 4, no. 12, pp. 1443-1451, 2005.

[24] S. E. Bizimenyera, G. E. Swan, H. Chikoto, and J. N. Eloff, "Rationale for using Peltophorum africanum (Fabaceae) extracts in veterinary medicine," Journal of the South African Veterinary Association, vol. 76, no. 2, pp. 54-58, 2005.

[25] T. L. Riss and R. A. Moravec, "Use of multiple assay endpoints to investigate the effects of incubation time, dose of toxin, and plating density in cell-based cytotoxicity assays," Assay and Drug Development Technologies, vol. 2, no. 1, pp. 51-62, 2004.

[26] J. L. MacLaughin, C. J. Chnag, and D. L. Smith, "Bench-top bioassays for the discovery of bioactive natural product: an update," Studies in Natural Product Chemistry, vol. 9, pp. 388409, 1991.

[27] M. P. Gupta, A. Monge, G. A. Karikas et al., "Screening of Panamanian medicinal plants for brine shrimp toxicity, crown gall tumor inhibition, cytotoxicity and DNA intercalation," Pharmaceutical Biology, vol. 34, no. 1, pp. 19-27, 1996.

[28] P. J. Jones, "Cholesterol-lowering action of plant sterols", Current Atherosclerosis Reports, vol. 1, no. 3, pp. 230-235, 1999.

[29] A. Chanwitheesuk, A. Teerawutgulrag, J. D. Kilburn, and N. Rakariyatham, "Antimicrobial gallic acid from Caesalpinia mimosoides Lamk," Food Chemistry, vol. 100, no. 3, pp. 10441048, 2007.

[30] D. A. Lewis and P. J. Hanson, "4 anti-ulcer drugs of plant origin," Progress in Medicinal Chemistry, vol. 28, pp. 201-231, 1991. 

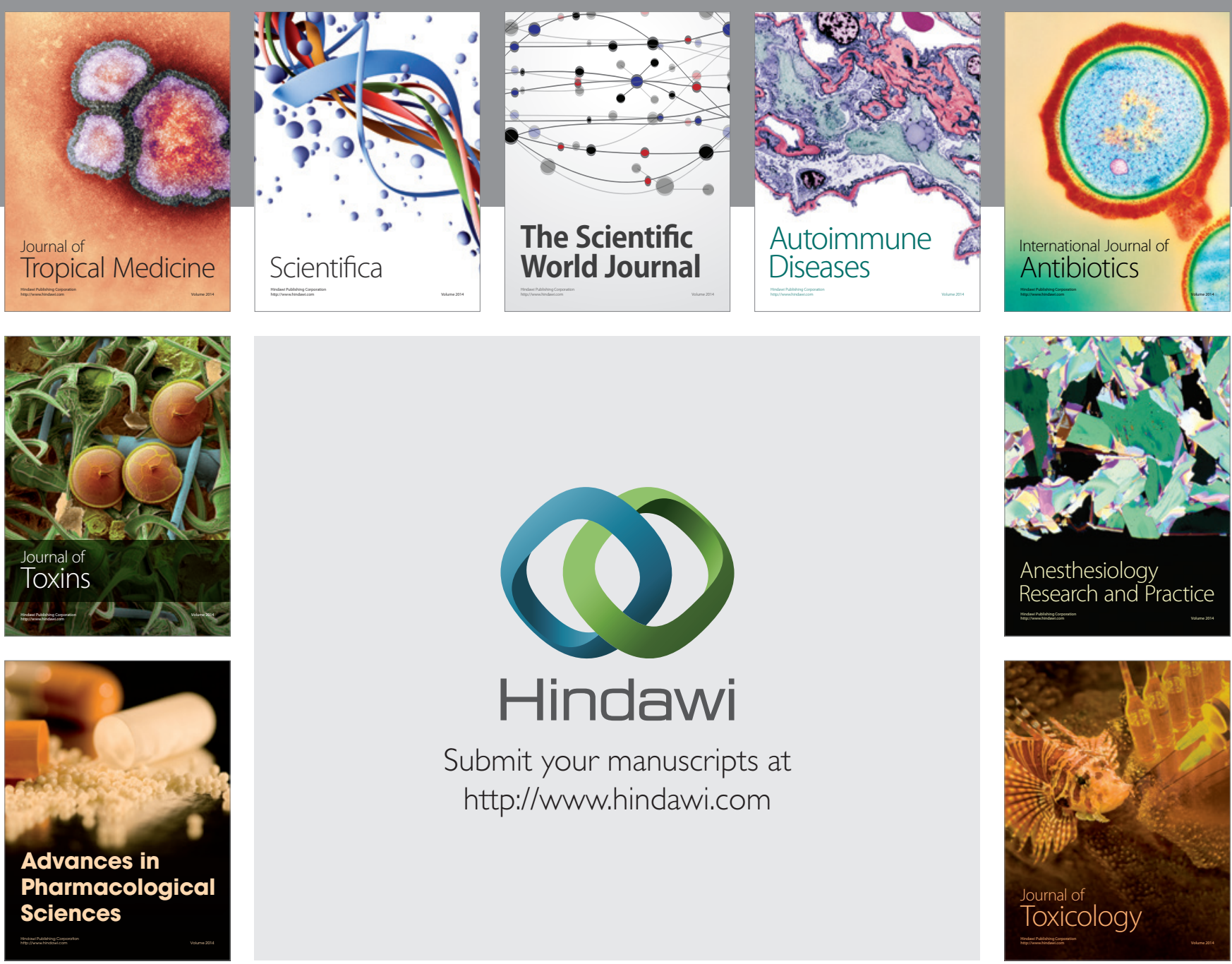

\section{Hindawi}

Submit your manuscripts at

http://www.hindawi.com
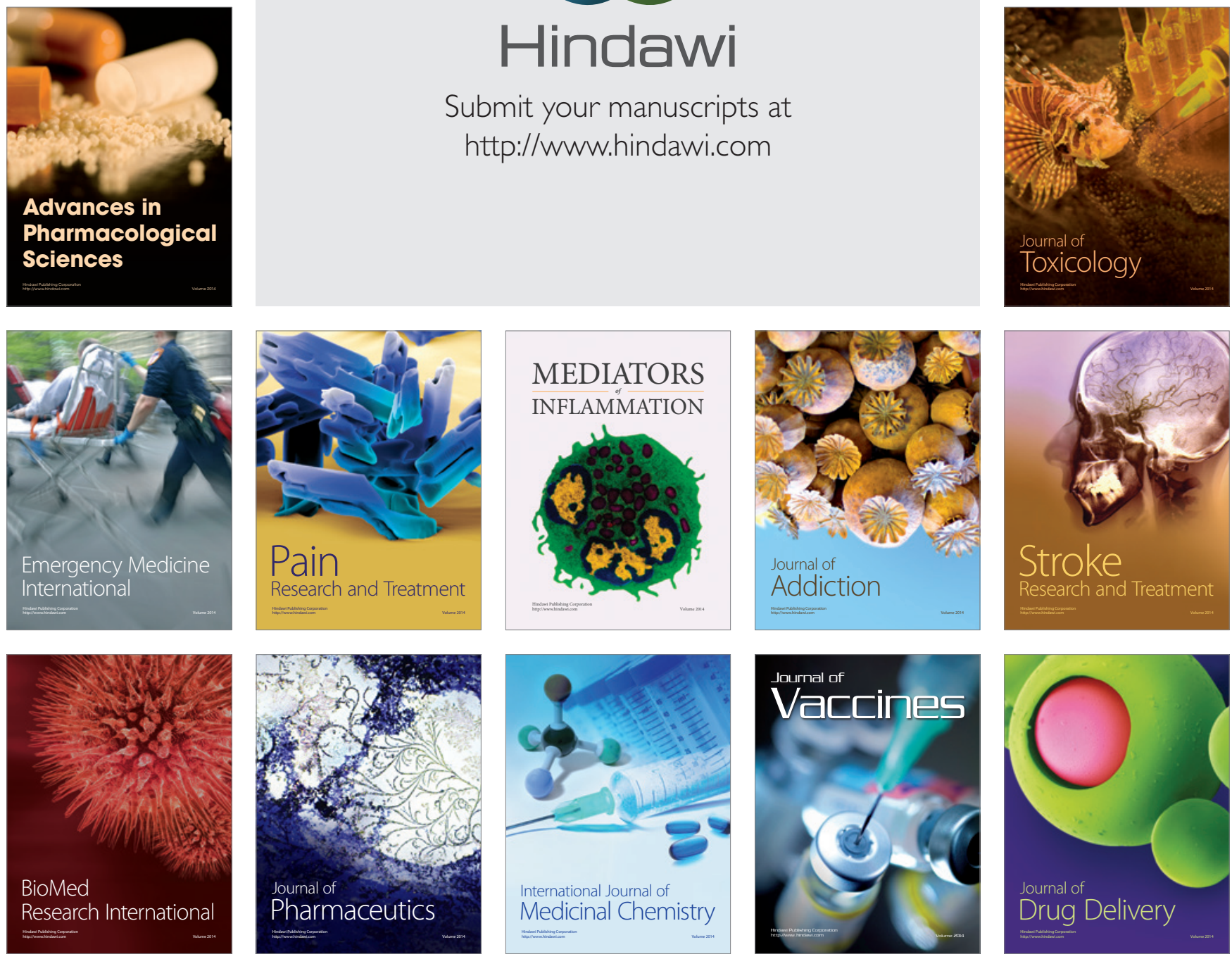